Hepatitis-B virus infection in sexually transmitted disease clinic attenders in an African city, (Jos, Nigeria)

Hepatitis-B virus (HBV) infection has become one of the most important infectious diseases the world over and especially in developing countries. ${ }^{1}$

Infection with HBV is predominantly parenteral. However, high prevalence of serologic markers of HBV among female prostitutes, STD clinic patients and homosexual men have been documented in many studies, ${ }^{2}$ from developed countries. This study was therefore designed to determine the prevalence of HBsAg in patients attending the STD clinic in Jos University Teaching Hospital, Jos.

One hundred adults (65 males and 35 females) who were attending the STD clinic of the Jos University Teaching Hospital, were screened for HBsAg. One hundred sex and aged matched controls were also screened.

About $5 \mathrm{ml}$ of venous blood was collected from each of the subjects between January and March, 1991. HBsAg was determined using the commercially available latex test kit (Biotex Laboratories).

The chi square test was used for statistical analysis.

Of the 100 STD patients sera assayed, HBsAg was detected in eight (7/65 males and $1 / 35$ females). Of the 100 controls 11 were HBsAg positive, (8/65 males and 3/35 females). There was no significant difference in the carrier rates of the groups and their sexes $(p>0.05)$ even though there was a three fold increase in the males compared with the females in the STD group.

The high prevalence of HBsAg in both groups studied, STD and control patients $(8 \%$ and $11 \%$ respectively) confirms the endemicity of $\mathrm{HBV}$ infection in Nigeria. There was no significant difference $(p>0.05)$ in the carrier rates of the two groups. This finding does not only suggest the endemicity of HBV infection in Nigeria but also the fact that sexual transmission may not play a significant role as a route of infection.

The figure $(8.0 \%)$ obtained for the STD patients in this study compares favourably with that obtained in the study $(9 \cdot 2 \%)$ by Gan $e^{2} \mathrm{al}^{3}$ among STD patients in Malaysia but was slightly higher than the figure $(5.43 \%)$ obtained by Osoba $e t \mathrm{al}^{4}$ at Ibadan, Nigeria.

This low prevalence by Osoba may be due to the lower sensitivity of the Agargel immunodiffusion method, a first generation serologic assay method as compared with the latex agglutination second generation method used in this study.

This study has re-emphasised the endemicity of HBV infection in the developing countries and the urgent need for intervention to eradicate this disease with its attendant morbidity and mortality.

We are grateful to all consultants whose patients were used in this study and to the authorities of Jos University Teaching Hospital that provided the facilities. We also thankfully acknowledge the secretarial assistance provided by Umaru Haruna of the Department of Paediatrics, University of Jos.

$$
\begin{array}{r}
\text { C S S BELLO } \\
\text { S O OPAJOBI } \\
\text { Deparment of Medical Microbiology } \\
\text { S N OKOLO } \\
\text { Paediatrics } \\
\text { R S OLAREWAJU } \\
\text { Obstetrics E Gynaecology } \\
\text { L O IDOKO } \\
\text { Community Medicine, Faculty of Medical Sciences, } \\
\text { University of fos, fos, Nigeria }
\end{array}
$$

1 Sobeslavky O. Prevalence of markers of hepatitis B virus infection in various countries: a WHO collaborative study. Bull WHO 1980;58:621-8.

2 Fulford KW, Dane DS, Catteral RD, et al. Australian antigen and antibody among patients attending a clinic for sexually transmitted diseases. Lancet 1973;i:170-4.

3 Gan CY, Yap SF, Ngeow YF, Wong HE. Hepatitis B infection among Chinese STD patients in Kuala Lumpur, Malaysia. Sex Transm Dis 1991;18:84-8.

4 Osoba AO, Smith JA, Alausa KO, Sogbetun AO. Australia antigen ( $\mathrm{HBsAg}$ ) in Genitourinary secretions of Nigerians. Trop Geogr Med 1975;27:181-4.

Accepted for publication 5 May 1992.

\section{Malignant syphilis in a teenage girl}

Syphilis, the great imitator was well recognised even in the 15th century as a sexually transmitted disease. Malignant syphilis has become of historical interest and is often associated with debilitation and poor socioeconomic conditions. Papulonodular syphilides are usually midway between the secondary and tertiary stages. Sometimes, they may be found in delayed relapse. ${ }^{1}$ This type may be confused with variola, varicella and furunculosis. As a result of the adjustment of the host-parasite relationship and under the impact of modern therapeutic agents, syphilis has now become mild and hence violent malignant syphilis raises problems in diagnosis.

An unmarried teenage girl, attended the STD Department, Government Rajaji Hospital, Madurai with skin rashes over all the body and two ulcers, one on each leg, of 20 days duration, referred from the Dermatology Department for the exclusion of a diagnosis of syphilis. She had had treatment in the infectious diseases hospital for the previous 15 days. She had had sexual intercourse with an unknown male (only once) 5 months previously. No history of trauma in the legs, transfusion or intravenous injections were recorded.

On general examination, she was febrile and had papulonodular skin eruptions all over the body and two circular ulcers, one in each leg, 